\title{
Environmental niche modelling of globally threatened yellow-throated bulbul, Pycnonotus xantholaemus for conservation prospects in the Deccan Peninsula, India
}

\author{
Ashish Jha and Karthikeyan Vasudevan* \\ CSIR-Centre for Cellular and Molecular Biology, Laboratory for the Conservation of Endangered Species, Hyderabad 500 048, India
}

\begin{abstract}
Yellow-throated bulbul (YTB), Pycnonotus xantholaemus is an endemic and threatened bird of the Deccan Peninsula which is found in discontinuous populations. We used MaxEnt algorithm to generate environmental niche models for further surveys. We compared the models for current and future scenarios to assess change in the extent of suitable habitat in response to climate change. We used 102 verified presence locations and six environmental variables: four climatic, one topographical and one vegetation layer to generate the final model. Topographic ruggedness index and precipitation of wettest month were the major predictors of suitable habitat. The predicted distribution amounting to $7 \%$ of the Deccan Peninsula was highly fragmented. Only $13.5 \%$ of the predicted habitat fell within the Protected Areas. Models predicted $6.5 \%-42 \%$ loss of habitat in different climate change scenarios, with a marginal gain in the western slopes of southern Western Ghats. Microclimatic features of the habitat may help determine the geographic distribution of YTB. This could serve as a nontraditional flagship species to highlight conservation of rocky outcrops in the Deccan Peninsula.
\end{abstract}

Keywords: Climate change, environmental niche models, endemic species, Pycnonotus xantholaemus, rocky outcrops.

YELLOW-THROATED bulbul, Pycnonotus xantholaemus (hereafter YTB) is one among 93 threatened birds from India $^{1,2}$. It is a passerine, endemic to scrub forests and dry deciduous forests of the Eastern Ghats, inland hillocks of the Deccan Peninsula and eastern slopes of the southern Western Ghats. It is restricted to scrub forests on hills with exposed rocky outcrops, and therefore, patchily distributed in the Deccan Peninsula ${ }^{3,4}$. YTB occurrences can be broadly assigned to three habitats, as described in Subramanya et al. $^{4}$ : (a) dry deciduous scrub and southern thorn forests - such areas are characterized by sparse

*For correspondence. (e-mail: karthik@ccmb.res.in) trees and scrub vegetation growing amidst large rocky outcrops - a majority of the records are from this habitat; (b) dry deciduous and mixed forest - this habitat has higher canopy cover than the dry deciduous scrub forest and (c) riparian and semi-evergreen forests - such habitats are moist with perennial streams or cascades. Almost all the information on its distribution and ecology comes from opportunistic sightings and locality records ${ }^{5}$. It is classified as 'vulnerable' in the IUCN Redlist based on the restricted distribution and ongoing habitat loss ${ }^{1}$.

Rocky outcrops that occur in the YTB habitat are referred to as granitic gneisses, charnockite series, khondalite series and granites ${ }^{6}$. Quarrying in the habitat for granite slabs and construction aggregate is a quintessential threat to the species. India is the leading exporter of granite and quarrying for granite is expected to expand in the region ${ }^{7}$. The geographic distribution of YTB is restricted to the southern states of India which hold $25 \%$ of the country's granite reserves ${ }^{8}$. The IUCN recommends lobbying against large-scale granite quarrying and raising awareness among masses as conservation measures for this species ${ }^{1}$. However, without scientific data on the geographic distribution and habitat associations of the YTB, these recommendations are muted.

Since knowledge about geographical distribution and habitat use forms the basis for successful conservation of rare species ${ }^{9}$, ecologists have relied upon environmental niche modelling (ENM) to develop conservation strategies ${ }^{10-12}$. ENM relates presence locations with a suite of environmental variables and predicts the fundamental ecological niche of a species ${ }^{13-15}$. The 'presence-only' ENM approach is useful for modelling the potential distribution of rare and elusive species, wherein ascertaining 'absence' in any location is tedious.

While non-climatic threats (e.g. anthropogenic pressure) and intrinsic threats (e.g. discontinuous population and low density) are predicted to negatively impact longterm survival of $\mathrm{YTB}^{1}$, the possible impact of climatic threats to the species is unexplored. The effects of climate change on endemic species are of particular concern, because they are restricted in distribution and 


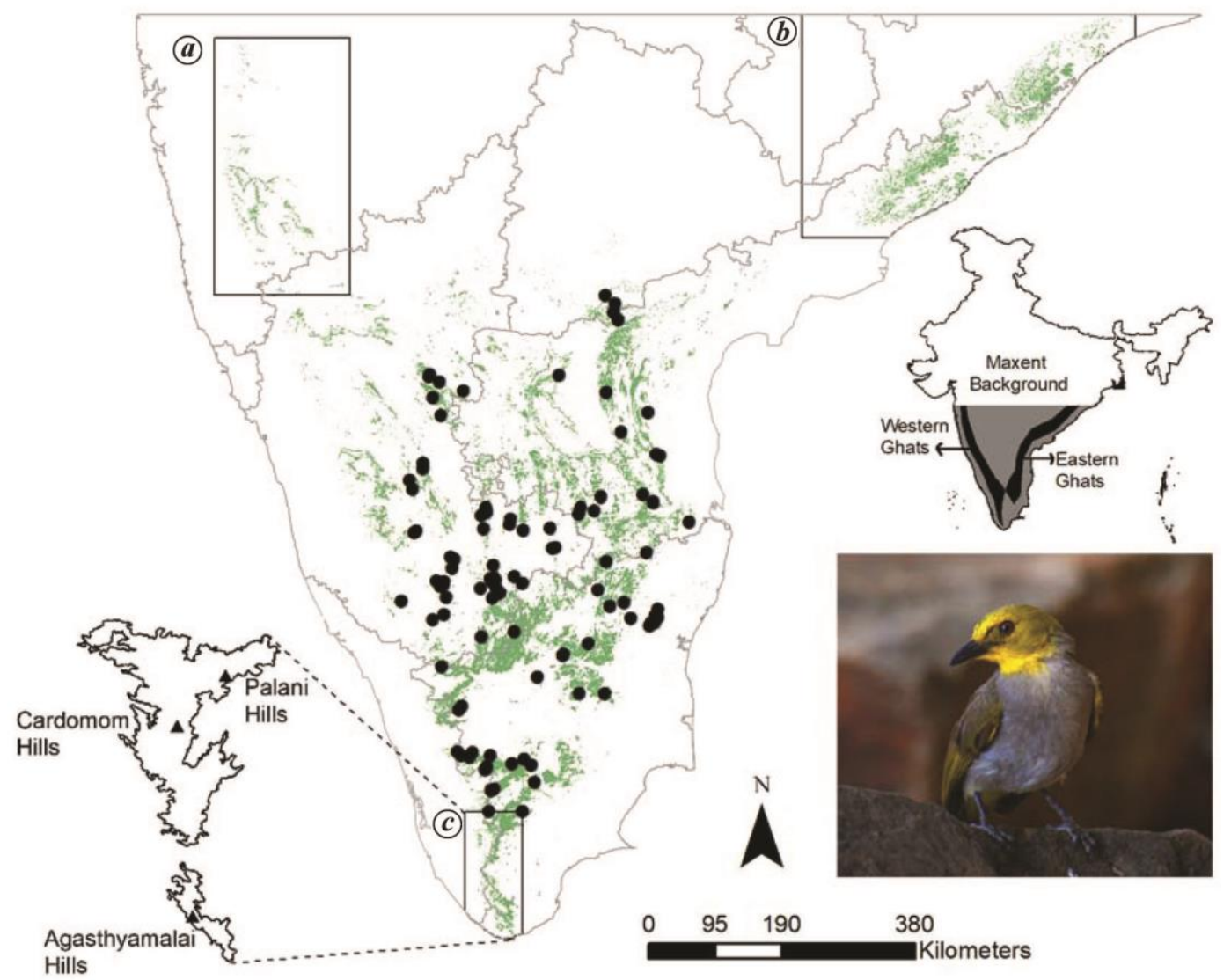

Figure 1. Environmental niche model for yellow-throated bulbul (YTB). The area shaded in green represents the predicted habitats of YTB. The lines demarcate the state boundaries. Black dots represent the occurrence records used to generate the model. The boxes represent: $(\boldsymbol{a})$ northern Western Ghats, $(\boldsymbol{b})$ northern Eastern Ghats, and $(\boldsymbol{c})$ southern Western Ghats showing prominent hill ranges. (Inset) Map of India showing the Eastern and Western Ghats; the shaded region is the background area used for the model. (YTB by A.J.).

might have highly specific habitat requirements that reduce their capability to adapt to climatic change ${ }^{16,17}$. The Intergovernmental Panel on Climate Change (IPCC) predicts rise in mean annual temperature of $2^{\circ}-4^{\circ} \mathrm{C}$ for most of India by the end of this century, increased precipitation and fewer rainy days leading to extreme rainfall events ${ }^{18}$.

There is surmounting evidence that climate change would adversely affect the distribution of species and their niches, and the timing of their life events such as reproduction, though the impact of climate change will vary depending on the local topography ${ }^{19-21}$. Unlike climatic data projections in the current scenario, where the model can be tested using independent data, climatic projections for a future scenario cannot be evaluated for their robustness since occurrence records are not available for the future ${ }^{22}$. Despite these shortcomings, predictive models can be used to assess the impact of climate change and could contribute towards conservation policy $^{23,24}$.

In this study, we modelled the geographic distribution of YTB in the Deccan Peninsula. Our objectives were to: (a) identify potential sites for the species and ascertain the extent of overlap of the predicted distribution of YTB with existing Protected Areas (PAs) in the Deccan Peninsula region, and (b) forecast the possible impact of climate change on the potential habitat distribution of YTB.

\section{Materials and methods}

\section{Background area}

The ENM predictions and performance are sensitive to the background geographic area selected ${ }^{25}$. This background must account for the ability of the species to disperse and availability of suitable habitat ${ }^{26}$. In this study, the Deccan Peninsula $\left(72^{\circ}-86^{\circ} \mathrm{E}\right.$ and $\left.8^{\circ}-20^{\circ} \mathrm{N}\right)$ was chosen as the background geographic area for modelling distribution of the YTB. It has three prominent geographical features - the Deccan plateau which is hemmed between two mountain ranges, viz. the Eastern Ghats and the Western Ghats (Figure 1). The latter is a near-continuous $1600 \mathrm{~km}$ hill range running north-south 


\section{RESEARCH ARTICLES}

Table 1. List of predictor variables used for generating environmental niche modelling, with their per cent contribution and permutation importance in the niche model

\begin{tabular}{|c|c|c|c|c|c|}
\hline Variable & $\begin{array}{l}\text { Per cent contribution/ } \\
\text { permutation importance }\end{array}$ & $\begin{array}{l}\text { Maximum } \\
\text { value }\end{array}$ & $\begin{array}{l}\text { Minimum } \\
\text { value }\end{array}$ & $\begin{array}{l}\text { Mean } \\
\text { value }\end{array}$ & $\begin{array}{l}\text { Standard } \\
\text { deviation }\end{array}$ \\
\hline $\begin{array}{l}\text { TRI - topographic ruggedness index (derived from digital } \\
\text { elevation map) }\end{array}$ & $63.5 / 68.8$ & 38.65 & 1.00 & 15.49 & 6.61 \\
\hline Bio13 - precipitation of wettest month $(\mathrm{mm})$ & $21.1 / 16.0$ & 418 & 114 & 183.35 & 52.14 \\
\hline Bio4 - temperature seasonality $(\mathrm{SD} \times 100)$ & $10.8 / 7.8$ & 3179 & 1195 & 2111.30 & 505.86 \\
\hline Bio10 - mean temperature of warmest quarter $\left({ }^{\circ} \mathrm{C} \times 10\right)$ & $2.3 / 3.2$ & 318 & 219 & 279.02 & 19.55 \\
\hline Bio6 - minimum temperature of coldest month $\left({ }^{\circ} \mathrm{C} \times 10\right)$ & $1.2 / 3.5$ & 198 & 124 & 163.52 & 17.71 \\
\hline $\begin{array}{l}\text { COV-NDVI - coefficient of variation of NDVI layers, } \\
\text { January 2011-2019 }\end{array}$ & $1.1 / 0.7$ & 0.30 & 0.07 & 0.17 & 0.05 \\
\hline
\end{tabular}

parallel to the west coast of the Deccan Peninsula. The Eastern Ghats is a discontinuous range of mountains running along the east coast of the Deccan Peninsula ${ }^{27}$. Several scattered inland hillocks and rock formations are found across the Deccan plateau. Both the Eastern Ghats and the Deccan plateau are located on the leeward side of the Western Ghats. They receive annual rainfall ranging from 200 to $1000 \mathrm{~mm}$ (https://en.climatedata.org/asia/india).

\section{Occurrence records}

We obtained permits to conduct field studies from the State Forest Departments of Telangana, Andhra Pradesh, Karnataka and Tamil Nadu. During the field surveys between 2015 and 2018, we recorded YTB in 28 different locations. We collected first-hand information on their habitat, behaviour, ecology and recorded habitat features such as elevation, vegetation, presence of water bodies, rocky outcrops and anthropogenic pressure. We collated 202 occurrence records based on our field visits and reported locations (various published literature, eBird ${ }^{28}$ records and personal communications; Supplementary Table 1). All the occurrence records compiled from secondary sources were screened and included in the study after verifying the records. Each of the records was projected using Google Earth ${ }^{\mathrm{TM}}$ and the location was selected if any one of the following criteria was met: (i) the species was reported by multiple and independent observers from the same location; (ii) a photograph of the species was available from the location or detailed field observations were recorded by the observer, and (iii) topography and vegetation of the location matched the description of YTB habitat. This was done to exclude eBird records from improbable locations such as city centres and water bodies. In case of any ambiguity, we contacted the observers and sought more information about the location before it was included the study. The eBird records are based on observations made by birdwatchers, and they have a strong bias towards accessible areas and tourist destinations. Such sampling bias leads to overrepresentation of environmental conditions prevailing in regions with high sample density ${ }^{29,30}$. In order to address this sampling bias, we performed spatial thinning in ArcGIS 10.3. A grid spaced by $2 \mathrm{~km}$ was overlaid on the locations, and only one location within a $2 \times 2 \mathrm{~km}$ cell was randomly selected. Although data were not available on home-range size of this species, we chose a conservative approach with the threshold of $2 \mathrm{~km} \times 2 \mathrm{~km}$ to ensure spatial independence of the occurrence records and to account for the homogeneity of the habitat. We used a final set of 102 presence points for generating ENM (Supplementary Table 1).

\section{Environmental variables}

The most widely used climatic dataset for ENM is the WorldClim global data layers which are based on an interpolation of average monthly climate data from weather stations for the period 1950 to 2000 (ref. 31). We obtained bioclimatic (WorldClim dataset v2.1, 1 sq. km resolution), topographic (digital elevation map, $\mathrm{DEM}^{32}$ ) and vegetation layers (normalized difference vegetation index (NDVI) layers, 1 sq. km resolution) from on-line sources (Table 1). The bioclimatic variables represent annual trends (e.g. mean annual temperature), seasonality (e.g. annual range in temperature) and extreme or limiting environmental factors (e.g. temperature of the coldest and warmest month $)^{31}$. DEM represents topographic features of the landscape. NDVI is a measure of the amount and vigour of vegetation on the land surface.

During field surveys, we observed mesic patches in the YTB habitat, created by water seeping through the rock crevices. The region surrounding these mesic patches supported a rich assembly of vegetation, many of which were food plants of YTB, e.g. Ficus amplissima, Ficus microcarpa, Ficus mollis, Erythroxylum monogynum, Premna tomentosa (pers. obs.). These mesic patches could be an important feature of YTB habitat, since they provide a perennial source of food and water in an otherwise dry landscape. To test this hypothesis, we created a raster layer of coefficient of variation of NDVI (CoVNDVI) to capture the 'evergreeness' of these mesic patches and used this as a predictor variable in ENM. We 
obtained fortnightly NDVI layers from Bhuvan (GeoPlatform of Indian Space Research Organisation; bhuvan. nrsc.gov.in) for the years 2011 to 2019. Layers for each month were pooled and averaged across the years. Mean and standard deviation of 12 such monthly layers were used to create $\mathrm{CoV}-\mathrm{NDVI}$ using raster calculator in ArcGIS 10.3. A low value for CoV-NDVI would suggest less intra-annual change in green cover while relatively dry areas without perennial water source would show a high value of CoV-NDVI. We used only the CoV-NDVI layer for further analysis and not the individual NDVI layers.

During exploratory data analyses, the preliminary models had a large weightage for elevation, and they did not predict YTB distribution in some prominent locations at low elevations. However, they predicted distribution in high elevation plateau areas, where there were no reports of YTB. This prompted us to create a layer of topographic ruggedness index (TRI). This index is a measure of the difference in the elevation between adjacent cells in a DEM. A TRI layer was created by calculating the difference in the elevation between a cell and eight neighbouring cells. Eight values obtained were squared to remove the sign and square root of the mean value was used ${ }^{33}$. We created TRI layer in ArcMap 10.3 and used it for further analyses, and excluded the DEM layer.

The layers were clipped for the background area and resolution of each layer was adjusted to $1 \mathrm{sq}$. $\mathrm{km}(30 \mathrm{~s})$ in ArcGIS 10.3. Out of the 19 bioclimatic variables, we eliminated layers that were correlated to each other (Pearson's $r>0.75$ ) to avoid multicollinearity ${ }^{34,35}$. Further, layers that contributed less than $2 \%$ to the preliminary model were also removed and the performance of the resulting model with reduced number of variables was measured using area under the curve (AUC), true skill statistics (TSS) and Akaike's information criterion (AIC) scores (Supplementary Table 2). For the final analysis, we used four bioclimatic variables, one topographic variable and one vegetation variable (Table 1). The layers were chosen considering the ecology of the species and to reflect features of its habitat. Since YTB mostly occurs in rugged and relatively dry terrain, we expect the model to predict positive association of logistic output (probability of presence) with TRI, and negative association with CoV-NDVI and precipitation.

\section{Modelling procedure and evaluation}

We implemented ENM in MaxEnt v3.3.3, a widely employed modelling approach using 'presence-only' data $^{34,36}$. It has been used to forecast species distribution for current scenarios, under climate change scenarios and influence conservation policies ${ }^{14,22,34}$. MaxEnt was set to pick at random $70 \%$ of occurrence records for model training, and the remaining 30\% occurrence records for model testing and 10,000 random points (pseudo- absences) from the background area. Feature classes and regularization multiplier were kept as default ${ }^{37}$. A set of 20 replicates of the model was run using bootstrap method, and the maximum number of iterations was set at 5000. We used logistic format as the output type. MaxEnt generates a continuous map of habitat suitability. We converted suitability values ranging from 0 to 1 into binary values 0 (not suitable), and 1 (suitable) using 'maximum test sensitivity plus specificity logistic threshold value', as it is known to perform better than other threshold values ${ }^{38}$.

We evaluated the efficiency of the model using AUC of the receiver operating characteristic (ROC) plot, TSS ${ }^{39}$ and $\mathrm{AIC}^{40}$. AUC measures the ability of the model to distinguish between the presence records, and the random background points. The AUC values range from 0.5 (not different from a randomly selected predictive distribution) to 1 (with perfect predictive ability). TSS is defined as one minus the sum of sensitivity and specificity (sensitivity is the proportion of correctly predicted presences, and specificity is the proportion of correctly predicted absences). It ranges from -1 to 1 . A value of one indicates perfect agreement. AIC is based on the principle of parsimony by including a penalty for the number of parameters and attempts to select a good approximate model $^{40}$. We used ENMtools v1.3 (ref. 41) to estimate AIC score of the models.

We overlaid the shapefiles of PAs over the predicted distribution of YTB to compare the extent of predicted distribution falling within PA network. Shapefiles of PAs were created manually in ArcGIS 10.3 using georeferenced PA maps as template (available from the database of Environmental Information System, ENVIS - Centre on Wildlife and Protected Areas; wiienvis.nic.in/).

\section{Climate change scenarios}

To understand the impact of climate change on the species distribution model of YTB, the model based on five predictor variables, with the exception of $\mathrm{CoV}-$ NDVI was projected in 2050 and 2070 climate change scenarios. We obtained bioclimatic data (WorldClim dataset v2.1 (ref. 31), 1 sq. km resolution) for the years 2050 and 2070. We used the CMIP5 (Coupled Model Inter comparison Project, Phase 5) climate projections from global climate models (GCMs - CCSM4) under all four possible representative concentration pathway (RCP) scenarios. RCP scenarios (RCP 2.6, RCP 4.5, RCP 6.0 and RCP 8.5) represent modelled greenhouse gas concentration trajectories till 2100. RCP 2.6 is the most optimistic (mitigation) scenario, RCP 4.5 and RCP 6.0 are stabilization scenarios, while RCP 8.5 represents very high baseline emission scenarios ${ }^{42}$. We converted suitability values ranging from 0 to 1 into binary values 0 (not suitable) and 1 (suitable) using 'maximum test sensitivity plus 


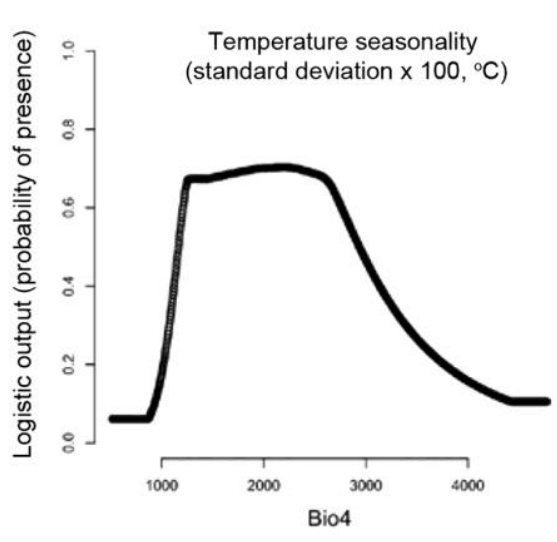

Precipitaton of Wettest month $(\mathrm{mm})$

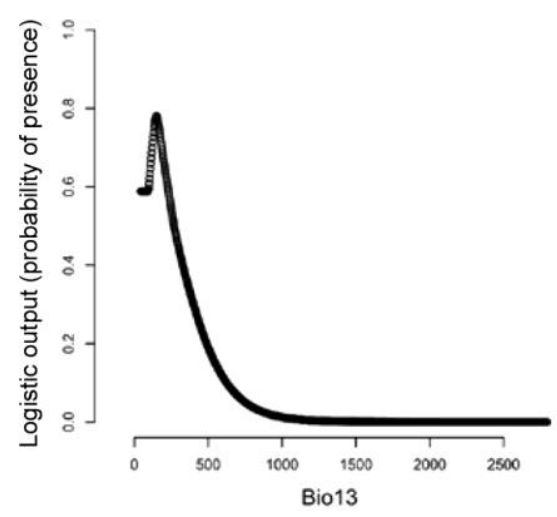

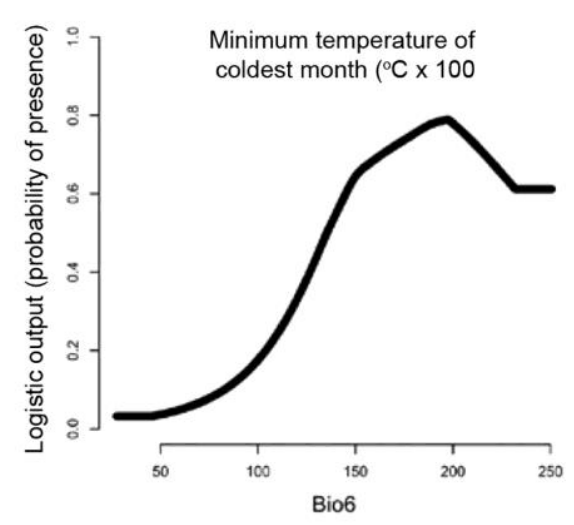

Tppographic ruggedness index

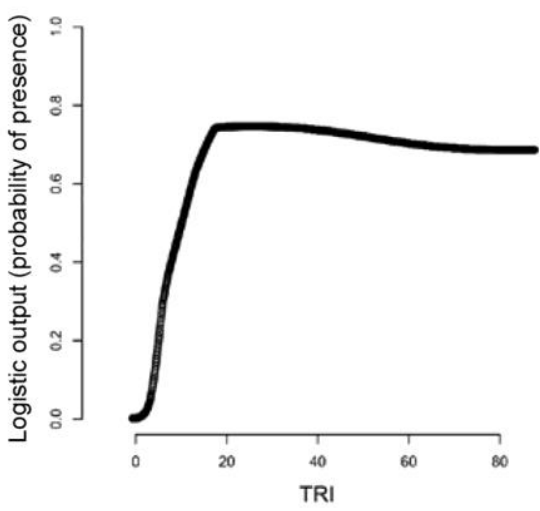

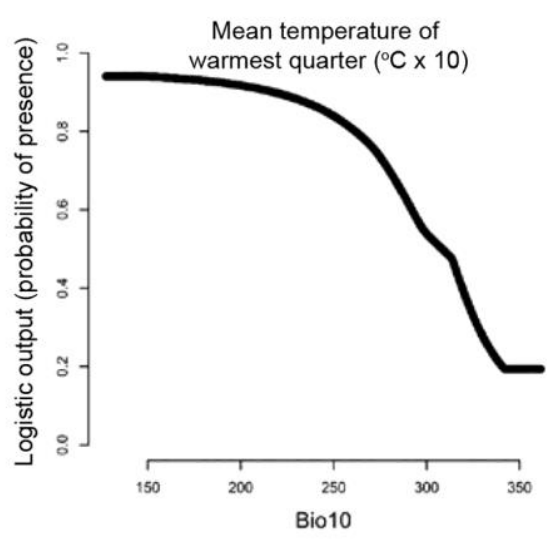

Coefficient of variation of NDVI

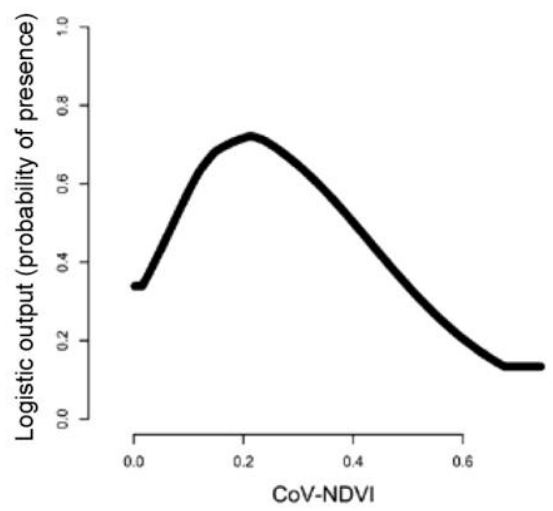

Figure 2. Response curves of variables used for ecological modelling for YTB. Mean response curve of 20 replicates is presented. Refer to Table 1 for description of the variables.

Table 2. Relative change in extent of suitable habitat (\%) with respect to current distribution for various climate change scenarios in 2050 and 2070

\begin{tabular}{lcccc}
\hline Scenario & $\begin{array}{c}\text { Threshold } \\
\text { value }\end{array}$ & $\begin{array}{c}\text { Total predicted } \\
\text { suitable habitat (sq. km) }\end{array}$ & $\begin{array}{c}\text { Percentage of } \\
\text { area gained }\end{array}$ & $\begin{array}{c}\text { Percentage } \\
\text { of area lost }\end{array}$ \\
\hline 2050 RCP 2.6 & 0.124 & 70,395 & 1.60 & 6.51 \\
2050 RCP 4.5 & 0.132 & 65,540 & 2.88 & 12.95 \\
2050 RCP 6.0 & 0.135 & 61,594 & 0.94 & 18.19 \\
2050 RCP 8.5 & 0.135 & 53,975 & 1.00 & 28.31 \\
2070 RCP 2.6 & 0.119 & 66,853 & 1.53 & 11.21 \\
2070 RCP 4.5 & 0.155 & 62,679 & 3.43 & 16.75 \\
2070 RCP 6.0 & 0.142 & 56,191 & 1.13 & 25.37 \\
2070 RCP 8.5 & 0.128 & 43,511 & 1.10 & 42.21 \\
\hline
\end{tabular}

specificity logistic threshold' value. We subtracted binary map (each cell has a value either 0 or 1 ) of future scenarios from the current scenario to measure change in the extent of predicted distribution. In the resulting raster, a value of 0 would mean no change (both future and current layer have the same value in overlapping cells). A value of 1 suggests the area will change into suitable habitat in the future (future layer has a higher value than the current layer). A value of -1 suggests that the area will change into unsuitable habitat in the future (future layer has a value less than the current layer).

\section{Results}

\section{Importance of the environmental variables}

TRI was the single-most important predictor variable, followed by precipitation of wettest period (Bio13) based on jackknife test and permutation importance of the environmental variables (Table 1). TRI, Bio13 and Bio4 (temperature seasonality) together explained $95 \%$ of variation in the model. As expected, species response curves for Bio4, mean temperature of warmest quarter (Bio10), 
Table 3. Predicted locations for surveys of yellow-throated bulbul

\begin{tabular}{ll}
\hline Location & \multicolumn{1}{c}{ District, state } \\
\hline Chakrageri Forest and Gokak Range Forest & Belgaum, Karnataka \\
$\begin{array}{l}\text { Kondapalli Reserve Forest } \\
\text { Kondaveedu Fort }\end{array}$ & Krishna, Andhra Pradesh \\
Northern Eastern Ghats & Guntur, Andhra Pradesh \\
& East Godavari and Vishakhapatnam, Andhra Pradesh; \\
Eastern slopes of the Southern Western Ghats & Gajapati and Ganjam, Odisha \\
\hline
\end{tabular}

CoV-NDVI and Bio13 showed a negative relationship with probability of YTB occurrence, while it showed positive relationship with TRI and Bio6 (minimum temperature of coldest month; Figure 2).

\section{Current potential distribution}

The best-fit model (AIC score $=2324.731$ ) based on six variables had good predictive performance and scored mean test AUC $0.971 \pm 0.01$ and mean TSS $0.882 \pm 0.03$ (Supplementary Table 2). The binary map (threshold $=0.147$ ) predicted an area of 75,298 sq. $\mathrm{km}$ as the suitable habitat. Predicted distribution was highly fragmented, with over $80 \%$ of fragments having area $<5 \mathrm{sq} . \mathrm{km}$. Some large and contiguous patches of suitable habitats were predicted along the Eastern Ghats and Western Ghats, while small and isolated habitat patches were predicted on the inland hillocks. In addition to localities in and around known areas of occurrences, the model predicted suitable habitats outside the known limits of distribution of the species in three geographic regions (Figure $1 a-c$ ). Out of the total predicted area, $2.7 \%$ (2036 sq. $\mathrm{km}$ ) was in the northern Western Ghats (Figure $1 a$ ), 12.4\% (9401 sq. km) is in the northern Eastern Ghats (Figure $1 b$ ), and $4.3 \%$ (3265 sq. km) in the southern Western Ghats (Figure $1 c$ ). Only $13.5 \%(10,236 \mathrm{sq} . \mathrm{km}$, Supplementary Table 1) of the total predicted habitat fell within the PA.

\section{Future potential distribution}

The model predicted a decline in the extent of suitable habitat in all possible future scenarios. Minimum predicted decline was $6.5 \%$ for 2050 , RCP 2.6 scenario and maximum predicted decline was $42 \%$ for 2070 , RCP 8.5 scenario (Table 2). The model predicted a decline in suitable habitat across the Eastern Ghats and inland hillocks with marginal gain in the extent of suitable habitat in the southern Western Ghats under all the climate change scenarios (Supplementary Figure 1).

\section{Discussion}

\section{Potential YTB habitat}

Suitable areas for YTB were predicted in the northern Western Ghats (Figure $1 a$ ), though there were no records of the species from this region, and the nearest record was $300 \mathrm{~km}$ south of this area. Prediction of suitable areas in the northern Eastern Ghats (Figure $1 b$ ) suggests that field surveys are required in this region to confirm presence of the species $^{3,43}$. So far there has been only one record of YTB from this region ${ }^{44}$. The model also predicted suitable areas in the southern Western Ghats (Agathyamalai Hills), and YTB has been recorded from Cardamom Hills and Palani Hills (Figure $1 c$ ). With few eBird records from all these regions, these could be less explored areas by bird-watchers. Due to rarity of the species, and the lack of birding effort in these areas, there might be unreported populations. Open rocky outcrops in the scrub forests and cascades that occur at $<1000 \mathrm{~m}$ elevation in these areas are potential sites for future field surveys (Table 3).

Terrain properties such as aspect and ruggedness are known to influence moisture and temperature regime at a small spatial scale $(<1 \mathrm{~km})$, thus creating a microclimate distinct from the rest of the region ${ }^{45,46}$. Such rocky outcrop ecosystems are known to have distinct vegetation and fauna in comparison to the surrounding environment ${ }^{47}$. Fine-scale microhabitat selection in such rocky outcrops has been reported in many diverse taxa ${ }^{47-49}$.

Our model suggests that topography and perennial mesic patches have a positive relation with the logistic output (probability of YTB presence) and negative relation with temperature seasonality. The scale used in the present study was too coarse to make any conclusive comment on the microhabitat selection by YTB. A fine-scale study would be more appropriate to estimate the influence of microclimate on YTB distribution.

\section{Current conservation status of YTB habitat}

The overlap between predicted area and PAs was in the Eastern Ghats (Papikonda Hills, Nallamalai Hills, Seshachalam Hills) and the Western Ghats (Billigirirangan Hills, Anaimalai Hills, Palani Hills, Cardamom Hills, Agasthyamalai Hills; Figure 3). These hill ranges overlap with $70 \%$ of the predicted YTB distribution. However, only $13.5 \%$ of YTB habitat fell within the large PAs in the Eastern Ghats and the Western Ghats (Figure 2). The inland hillocks had the remainder $30 \%$ of the predicted distribution of YTB, and this area is largely unprotected. Inland hillocks represent significant portion of known 


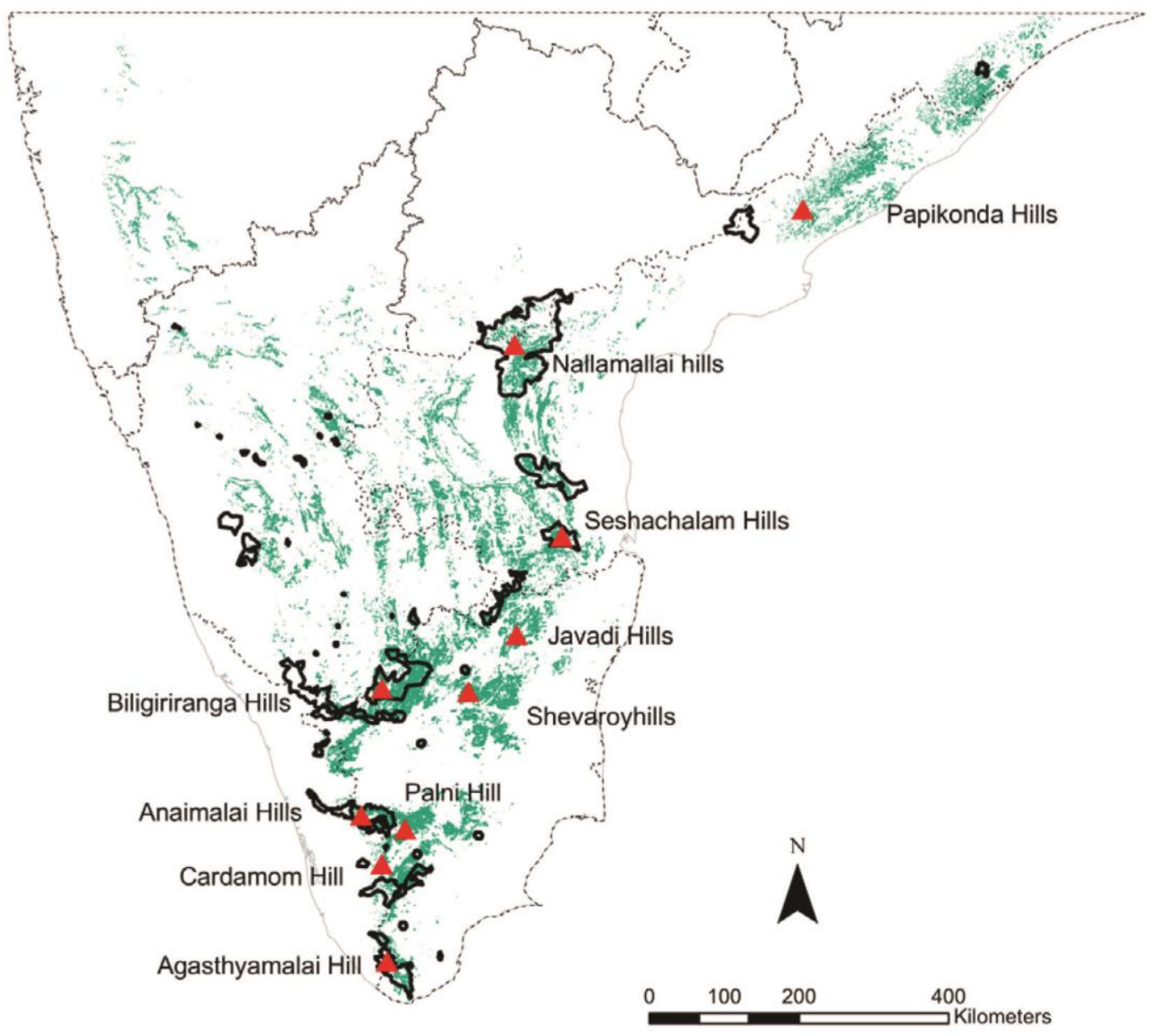

Figure 3. Map of Peninsular India showing overlap between predicted habitats of YTB and Protected Areas (PAs) Predicted extent of suitable habitat is shown in green. Dark lines demarcate the extent of PAs, while red triangles show the location of prominent hill ranges in the region.

YTB locations, but they are scattered and excluded from PA cover. Such isolated and small habitat patches face higher probability of local extinction ${ }^{50}$ and hence, such areas must be brought under the PA network. A network of small conservation areas would be a suitable conservation strategy for species such as YTB that occupy multiple discrete sites ${ }^{51}$.

\section{Impact of potential climate change on YTB habitat}

The model predicts a decline in the extent of suitable areas across the current of YTB range in future. Due to climate change, there could be more net loss $(6 \%-42 \%)$ in suitable gain $(1 \%-3.5 \%)$ for YTB across all climate change scenarios. At present, the species is reported from the eastern slopes of the Western Ghats at elevation ranging from 200 to $900 \mathrm{~m}$ amsl. Above this elevation the vegetation transitions into the evergreen type, which is unsuitable for YTB. Under the climate change scenarios, the western slopes that presently receive high rainfall would progressively get warm and dry ${ }^{52}$. This might provide new habitats for the species beyond its present distribution limits in the Western Ghats. It must be noted that both intrinsic (life-history traits and behaviour) and extrinsic (climate-change driven threats and anthropogenic pressure) factors determine the response of species to climate change ${ }^{53}$. YTB is a behaviourally timid spe$\operatorname{cies}^{3,54}$, and climate-change driven range shifts might expose it to competition from sympatric red-vented bulbul, Pycnonotus cafer and white-browed bulbul, Pycnonotus luteolus. The present model does not take into consideration shift in phenology of YTB food plants and altered temporal concordance with YTB reproduction. More indepth assessment of climate change impact on various taxa such as plants, insects and birds in the region would help in devising mitigation strategies. Long-term monitoring programme of such species will be key to enhancing our understanding of the climate change impact ${ }^{55}$.

\section{Conservation of YTB and its habitat}

The habitat occupied by YTB does not receive the desired levels of protection due to absence of any charismatic 
species in these landscapes ${ }^{56}$. Inland hillocks constitute one-third of the predicted suitable habitat, but roughly $90 \%$ of occurrence records are from inland hillocks. This is due to the ease of access to inland hillocks for birdwatchers. The observations contributed by the birding community are an invaluable resource for understanding the distribution and abundance of YTB and it could help in monitoring of its populations.

Since flagship species inspire conservation actions and secure habitats ${ }^{57,58}$, YTB should be considered as a 'non-traditional' flagship species for protection of rocky outcrops in the Deccan Peninsula of India ${ }^{59}$.

1. BirdLife International, Pycnonotus xantholaemus, The IUCN Red List of Threatened Species 2016, e.T22712719A94345114.

2. Praveen, J., Jayapal, R. and Pittie, A., Threatened birds of India (v2.1), 2019; http://www.indianbirds.in/india/ (accessed on 24 November 2020).

3. Ali, S. and Ripley, S. D., In Handbook of the Birds of India and Pakistan, Compact edition, Oxford University Press, New Delhi, 1987, vol. 6, pp. 93-96.

4. Subramanya, S., Prasad, J. N. and Karthikeyan, S., Status, habitat, habits and conservation of yellow-throated bulbul Pycnonotus xantholaemus (Jerdon) in South India. J. Bombay Nat. Hist. Soc., 2006, 103, 215-226.

5. Pittie, A., Bibliography of South Asian Ornithology, 2018; http://www.southasiaornith.in (accessed on 9 January 2019).

6. Sriramadas, A., Geology of Eastern Ghats in Andhra Pradesh. Proc. Indian Acad. Sci. - Sect. B, 1967, 66, 200-205.

7. MoM, Annual Report 2018-19, Ministry of Mines, Government of India; mines.gov.in

8. Indian Bureau of Mines, Indian Mineral Industry at a Glance 2015-16, The Mining and Mineral Statistics Division, MoM, GoI, 2018; https://ibm.gov.in/writereaddata/files/05092018145252IMIG-2015-16_advance\%20release-mod.pdf

9. Margules, C. R. and Pressey, R. L., Systematic conservation planning. Nature, 2000, 405, 243-253.

10. Peterson, A. T. and Robins, C. R., Using ecological-niche modelling to predict barred owl invasions with implications for spotted owl conservation. Conserv. Biol., 2003, 17, 1161-1165.

11. Raxworthy, C. J., Martínez-Meyer, E., Horning, N., Nussbaum, R. A., Schneider, G. E., Ortega-Huerta, M. A. and Peterson, A. T., Predicting distributions of known and unknown reptile species in Madagascar. Nature, 2003, 426, 837-841.

12. Sánchez-Cordero, V., Cirelli, V., Munguía, M. and Sarkar, S., Place prioritization for biodiversity content using species ecological niche modelling. Biodivers. Inform., 2005, 2, 11-23.

13. Guisan, A. and Zimmermann, N. E., Predictive habitat distribution models in ecology. Ecol. Model., 2000, 135, 147-186.

14. Elith, J. and Leathwick, J. R., Species distribution models: ecological explanation and prediction across space and time. Annu. Rev. Ecol. Evol. Syst., 2009, 40, 677-697.

15. Soberon, J. and Peterson, A. T., Interpretation of models of fundamental ecological niches and species' distributional areas. Biodivers. Inform., 2005, 2, 1-10.

16. Lawton, A. J. H., Daily, G. and Newton, I., Population dynamic principles. Philos. Trans. R. Soc. London B Ser., 1994, 344, 61-68.

17. Jones, M. C., Dye, S. R., Fernandes, J. A., Frölicher, T. L., Pinnegar, J. K., Warren, R. and Cheung, W. W. L., Predicting the impact of climate change on threatened species in UK waters. PLOS ONE, 2013, 8(1), e54216.

18. NIC, India: the impact of climate Change to 2030: a commissioned research report, NIC 2009-03D, National Intelligence Council; https://www.dni.gov/files/documents/climate2030-india.pdf
19. Julliard, R., Jiguet, F. and Couvet, D., Evidence for the impact of global warming on the long-term population dynamics of common birds. Proc. R. Soc. London, Ser. B, 2004, 271, S490-S492.

20. Parmesan, C. and Yohe, G., A globally coherent fingerprint of climate change impacts across natural systems. Nature, 2003, 421, $37-42$.

21. Bellard, C., Bertelsmeier, C., Leadley, P., Thuiller, W. and Courchamp, F., Impacts of climate change on the future of biodiversity. Ecol. Lett., 2012, 15, 365-377.

22. Hijmans, R. J. and Graham, C. H., The ability of climate envelope models to predict the effect of climate change on species distributions. Global Change Biol., 2006, 12, 2272-2281.

23. Porfirio, L. L., Harris, R. M. B., Lefroy, E. C., Hugh, S., Gould, S. F., Lee, G. and Mackey, B., Improving the use of species distribution models in conservation planning and management under climate change. PLoS ONE, 2014, 9, e113749.

24. Wiens, J. A., Stralberg, D., Jongsomjit, D., Howell, C. A. and Snyder, M. A., Niches, models, and climate change: assessing the assumptions and uncertainties. Proc. Natl Acad. Sci. USA, 2009, 106, 729-19736.

25. VanDerWal, J., Shoo, L. P., Graham, C. and Williams, S. E., Selecting pseudo-absence data for presence-only distribution modelling: how far should you stray from what you know? Ecol. Model., 2009, 220, 589-594.

26. Barve, N., Barve, A., Jime'nez-Valverde, A., Lira-Noriega, Maher, S. P., Peterson, A. T., Soberón, J. and Villalobos, F., The crucial role of the accessible area in ecological niche modelling and species distribution modelling. Ecol. Model., 2011, 222, 1810-1819.

27. Banerji, P. K., On the geology of the Eastern Ghats of Orissa and Andhra Pradesh, India. Development Precambrian Geol., 1990, 391-407.

28. eBird: An online database of bird distribution and abundance http://www.ebird.org (accessed on 2 February 2019).

29. Williams, P. H., Margules C. R. and Hilbert D. W., Data requirements and data sources for biodiversity priority area selection. J. Biosci., 2002, 27, 327-338.

30. Kadmon, R., Farber, O., and Danin, A., Effect of roadside bias on the accuracy of predictive maps produced by bioclimatic models. Ecol. Appl., 2004, 14, 401-413.

31. Hijmans, R. J., Cameron, S. E., Parra, J. L., Jones, P. G. and Jarvis, A., Very high resolution interpolated climate surfaces for global land areas. Int. J. Climatol., 2005, 25, 1965-1978; www.worldclim.org

32. USGS, Earth Resources Observation and Science (EROS) Center, SRTM data products; USGS.gov (accessed on 21 December 2018).

33. Riley, S. J., DeGloria, S. D. and Elliot, R., A terrain ruggedness index that quantifies topographic heterogeneity. Intermt. J. Sci., 1999, 5, 1-4.

34. Merow, C., Smith, M. J. and Silander Jr, J. A., A practical guide to MaxEnt for modelling species' distributions: what it does, and why inputs and settings matter. Ecography, 2013, 36, 1058-1069.

35. Elith, J., Phillips, S. J., Hastie, T., Dudík, M., Chee, Y. E. and Yates, C. J., A statistical explanation of MaxEnt for ecologists. Divers. Distrib., 2011, 17, 43-57.

36. Phillips, S. J., Dudík, M. and Schapire, R. E., A maximum entropy approach to species distribution modelling. In Machine Learning (ed. Brodley, C. E.). In Proceedings of the Twenty-first International Conference on Machine Learning, Banff, Canada, ACM Press, 2004, p. 83.

37. Phillips, S. J. and Dudik, M., Modelling of species distributions with Maxent: new extensions and a comprehensive evaluation. Ecography, 2008, 31, 161-175.

38. Liu, C., White, M. and Newell, G., Selecting thresholds for the prediction of species occurrence with presence-only data. J. Biogeogr., 2013, 40, 778-789. 
39. Allouche, O., Tsoar, A. and Kadmon, R., Assessing the accuracy of species distribution models: prevalence, kappa and the true skill statistic (TSS). J. Appl. Ecol., 2006, 43, 1223-1232.

40. Johnson, J. B. and Omland, K. S., Model selection in ecology and evolution. Trends Ecol. Evol., 2004, 19(2), 101-108.

41. Warren, D. L., Glor, R. E. and Turelli, M., ENMTools: a toolbox for comparative studies of environmental niche models. Ecographysics, 2010, 1, 607-611.

42. van Vuuren, D. P. et al., The representative concentration pathways: an overview. Climate Change, 2011, 109, 5.

43. Subramanya, S., Does the Yellow-throated bulbul Pycnonotus xantholaemus occur in Orissa? Newslett. Birdwatchers, 2004, 1, 39-40.

44. Sreekar, R. and Srinivasulu, C., New site record of yellowthroated bulbul Pycnonotus xantholaemus from Andhra Pradesh. Indian Birds, 2010, 5, 157.

45. Dobrowski, S. Z., Abatzoglou, J. T., Greenberg, J. A. and Schladow, S. G., How much influence does landscape scale physiography have on air temperature in a mountain environment? Agric. For. Meteorol., 2009, 149, 1751-1758.

46. Daly, C., Conklin, D. R. and Unsworth, M. H., Local atmospheric decoupling in complex topography alters climate change impacts. Int. J. Climatol., 2010, 30, 1857-1864.

47. Michael, D. R., Cunningham, R. B. and Lindenmayer, D. B., A forgotten habitat? Granite inselbergs conserve reptile diversity in fragmented agricultural landscapes. J. Appl. Ecol., 2008, 45, 1742-1752.

48. Agarwal, I., Bauer, A. M., Giri, V. B. and Khandekar, A., An expanded ND2 phylogeny of the brookii and prashadi groups with the description of three new Indian Hemidactylus Oken (Squamata: Gekkonidae). Zootaxa, 2019, 4619(3), 431-458.

49. Visinoni, L., Pernollet, C. A., Desmet, J., Korner-Nievergelt, F. and Jenni, L., Microclimate and microhabitat selection by the Alpine rock ptarmigan (Lagopus muta helvetica) during summer. J. Ornithol., 2015, 156, 407-417.

50. Wilcox, B. A. and Murphy, D. D., Conservation strategy: the effects of fragmentation on extinction. Am. Nat., 1985, 125, 879887.

51. Boyd, C. et al., Spatial scale and the conservation of threatened species. Conserv. Lett., 2008, 1, 37-43.
52. Indian Network for Climate Change Assessment, Climate change and India: a $4 \times 4$ assessment, a sectoral and regional analysis for 2030s, Ministry of Environment and Forests, GoI, 2010 http://www.indiaenvironmentportal.org.in/files/fin-rpt-incca.pdf (accessed on 30 April 2019).

53. Jiguet, F., Gadot, A. S., Julliard, R., Newson, S. E. and Couvet, D., Climate envelope, life history traits and the resilience of birds facing global change. Global Change Biol., 2007, 13, 1672-1684.

54. Allen, P. R., Notes on the yellow-throated bulbul Pycnonotus xantholaemus. J. Bombay Nat. Hist. Soc., 1908, 18, 905-907.

55. Galewski, T. and Devictor, V., When common birds became rare: historical records shed light on long-term responses of bird communities to global change in the largest wetland of France. PLoS ONE, 2016, 11(11), e0165542.

56. Rahmani, A., Threatened birds of India: need for immediate conservation action. J. Bombay Nat. Hist. Soc., 2010, 106, 1-3.

57. Simberloff, D., Flagships, umbrellas, and keystones: is singlespecies management passé in the landscape era? Biol. Conserv. 1998, 83, 247-257.

58. Entwistle, A., Flagship for the future. Oryx, 2000, 34, 239-240.

59. Jha, A. and Vasudevan, K., Demographic history of the fragmented yellow-throated bulbul (Pycnonotus xantholaemus) population in the Deccan Peninsula, India. Endanger. Species Res., 2020, 43 199-207; doi:https://doi.org/10.3354/esr01062.

ACKNOWLEDGEMENTS. We thank the State Forest Departments of Telangana (Rc. No. 43505/2013/WL-1), Andhra Pradesh (Rc. No. 9754/2014/WL-3), Karnataka (PCCF/(WL)/E2/CR/53/2016-17) and Tamil Nadu (WL(A)/4730/2017)) for permission to conduct field studies. We also thank H. S. Prayag, Karnataka Veterinary, Animal and Fisheries Sciences University, Bengaluru, for assistance during fieldwork at Karnataka.

Received 31 December 2019; revised accepted 5 September 2020

doi: $10.18520 / \mathrm{cs} / \mathrm{v} 119 / \mathrm{i} 11 / 1815-1823$ 